\section{In vitro Decarboxylation of Tryptophans by Mammalian Decarboxylase}

TwENTY-Two tryptophans have been examined in order to check the specificity of the so-called 5hydroxytryptophan decarboxylase ${ }^{1,2}$, and at the same time to see whether any of these compounds could be decarboxylated at a rate similar to that known for 5-hydroxytryptophan (5-HTP). The present work was intended as preliminary to further investigations on the possibility of non-biogenic tryptophans interfering in the biosynthesis, actions and metabolism of endogenous 5-hydroxytryptamine (5-HT), especially of brain 5-HT.

The tryptophans examined were the following: L-tryptophan, DL-5-hydroxytryptophan, DL-4hydroxytryptophan (4-HTP), DL-6-hydroxytryptophan, DL-7-hydroxytryptophan, DL-2-hydroxytryptophan, DL- $\alpha$-iso-5-hydroxytryptophan, DL-5-methyltryptophan, DL-5-methoxytryptophan, DL-5-benzyloxytryptophan, DL-5-nitrotryptophan, DL-5-aminotryptophan, DL-5-hydroxy- $\beta$-methyltryptophan, DL-5hydroxy-N,N-dimethyltryptophan, DL-5-hydroxy-6methoxytryptophan, DL-5-hydroxy-2-methyltryptophan, DL-5-benzyloxy-6-methoxytryptophan, DL-5hydroxy-N-acetyltryptophan, DL-5-acetoxy-N-acetyltryptophan, DL-4-methyltryptophan, DL-4-benzyloxytryptophan, pL-6-benzyloxytryptophan.

The enzyme preparations were obtained by centrifugation of homogenates of different guinea pig, rat, mouse and rabbit tissues in a Spinco preparative centrifuge, at 15,000 r.p.m. Decarboxylation was carried out in a conventional Warburg apparatus, at $38^{\circ} \mathrm{C}$. and $p \mathrm{H} \mathrm{7 \cdot 4}$. The flasks contained $4 \mathrm{~m}$.moles of the substrate amino-acid, $50 \mu \mathrm{mgm}$. pyridoxal phosphate, 0.07 umole phosphate buffer, $p H$ 7.4, and $2 \mathrm{ml}$. of the enzyme preparation, corresponding to $1 \mathrm{gm}$. fresh tissue. The total volume in the flasks was $2.4 \mathrm{ml}$. Carbon dioxide produced was determined 15 min. after the addition of $0.2 \mathrm{ml}$. of $N$ sulphuric acid.

Of the tryptophans examined only 5-HTP, 4-HTP, 5-hydroxy-N-acetyltryptophan and 5-acetoxy-Nacetyltryptophan were found to be decarboxylated using the above conventional, and not very sensitive, Warburg technique.

Howevor, as clearly shown by in vivo studies, decarboxylation of 5-hydroxy-N-acetyltryptophan and 5-acetoxy-N-acetyltryptophan was preceded by their hydrolysis to 5-HTP. Thus, only 5-HTP and 4-HTP actually acted as substrates for the decarboxylase.

Table 1 shows the results of a $30-\mathrm{min}$. incubation of DL-5-HTP, DL-4-HTP and dopa (3,4-dihydroxyphenylalanine was used only for the sake of comparison) with enzyme preparations from various tissues.

The carbon dioxide expected for complete decarboxylation was $44.7 \mu \mathrm{l}$. Addition of a mixture of 4-HTP and 5-HTP to a guinea pig kidney decarboxylase preparation led to a stoichiometric liberation of carbon dioxide consistent with the decarboxylation of both substrates.

The enzymic activity of the guinea pig kidney preparation was strongly inhibited, at $p \mathrm{H}_{6} \cdot 8$, by the addition of $\alpha$-methyldopa $(8 \mu$ moles), caffeic acid $(8 \mu \mathrm{moles})$ and cynarine $(8 \mu \mathrm{moles})$. However, inhibition of decarboxylation of 5-HTP was more complete than that of 4-HTP and dopa.

In sharp contrast to dopa, neither 5-HTP nor 4-HTP was attacked by bacterial decarboxylase (acetone-dried cells of Streptococcus faecalis R.).
Table 1. In nitro DECARBOXYLATION OF 5-HTP, 4-HTP AND DOPA

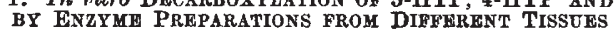

\begin{tabular}{|c|c|c|}
\hline Enzyme preparation & Substrate & $\begin{array}{l}\text { Carbon dioxide formed } \\
\text { in } 30 \mathrm{~min} .(\mu \mathrm{l} .)\end{array}$ \\
\hline $\begin{array}{l}\text { Guinea pig liver } \\
\text { ", ", kid̉ney } \\
\text { ", ", ", } \\
\text { ", }, " \text { intestine } \\
\text { Rat intestine ", } \\
\text { ", ", } \\
\text { Mouse brain } \\
\text { Räbibit lüng } \\
\text { ", ," }\end{array}$ & $\begin{array}{l}\text { 5-HTP } \\
\text { 4-HTP } \\
\text { 5-HTP } \\
\text { 4-HTP } \\
\text { Dopa } \\
\text { 5-HTP } \\
\text { 4-HTP } \\
\text { Dopa } \\
\text { 5-HTP } \\
\text { 4-HTP } \\
\text { Dopa } \\
\text { 5-HTP } \\
\text { 4-HTP } \\
\text { 5-HTP } \\
\text { 4-HTP }\end{array}$ & $\begin{array}{l}32 \cdot 0 \\
39 \cdot 0 \\
42 \cdot 2 \\
33 \cdot 0 \\
41 \cdot 5 \\
37 \cdot 5 \\
36 \cdot 5 \\
40 \cdot 0 \\
0 \\
0 \\
0 \\
12 \cdot 5 \\
20 \cdot 0 \\
0 \\
0\end{array}$ \\
\hline
\end{tabular}

The above experimental results show that the socalled 5-HTP-decarboxylase is not an enzyme spocific to 5-HTP, and that 4-HTP may bo the precursor amino-acid of the 4-hydroxyindolealkylamines (psilocin and psilocybin) occurring in the living organism. In a recent peper, Udenfriend, Lovenberg and Weissbach ${ }^{3}$ also suggest that the existence of separate dopa and 5-HTP decarboxylase should be withdrawn.

We are indebted to Prof. D. D. Woods, Department of Biochemistry, University of Oxford, who kindly supplied samples of acetone-dried cells of Streptococcus faecalis R.; L-tryptophan, DL-5-methyltryptophan and DL-4-methyltryptophan were purchased from Hoffmann-La Roche, Basle; DL- $\alpha$-iso-5-hydroxytryptophan was kindly supplied by Dr. F. Häfliger, J. R. Geigy A.G., Basle; DL-5-nitrotryptophan and DL-5-aminotryptophan were kindly supplied by Dr. G. Cavallini, Vismara Terapeutici, Milan; all the other tryptophans were synthesized in the Farmitalia Research Laboratories, Milan.

\section{ERspamer}

A. GLäSSER

C. PASInI

G. Stoppani

Research Laboratories, Farmitalia S.p.A.,

Milan, and

Institute of Pharmacology, University of Parma.

${ }^{2}$ Clark, C. T., Weissbach, H., and Udenfriend, S., J. Biol. Chem., 210, 139 (1954).

${ }^{2}$ Freter, K., Weissbach, H., Redfleld, B., Udenfriend, S., and Witkop, B., J."Amer. Chem. Soc., 80, 983 (1958). 8 Udenfriend, $S$., Lovenberg, W. M., and Weissbach, H., Fed. Proc.,
19, 7 (1960).

\section{An Evaluation of the Use of Digitonin for the Analysis of Frcal Sterols}

Numerous reports have appeared in the literaturo dealing with the analysis of fecal sterols ${ }^{1-3}$. Before the complexity of the sterol mixture of fæces was appreciated ${ }^{4}$, a commonly employed procedure for the analysis of coprostanol was based on the difference between the total sterol determined by gravimetric analysis of the digitonide of the mixture and the amount of cholesterol or 'chromogenic sterol' calculated from the colour produced with the LiebermannBurchard reagent ${ }^{1,2}$. While many investigators recognize that the chromogenic property of coprostanol will introduce an error in the analysis if coprostanol is determined as cholesterol using the 